\title{
The Italian Transition that Never Was
}

Martin J. Bull

University of Salford

The recent argument that the notion of 'transition' should be set aside in attempting to explain the trajectory of Italian politics in the past two decades is to be welcomed, but does not go far enough in explaining why we, as Italianists, got our case wrong and how exactly we might get our case right today. The transitional 'myth' was born and maintained despite growing evidence of its inherently problematic nature, both in conceptual and empirical terms. The concept of 'transition' needs more serious conceptual treatment and empirical application, but even with this work it is unlikely to be concluded that Italy is in transition. Freeing Italy and Italianists from this conventional wisdom, while, at the same time, not abandoning the idea that something exceptional happened to Italian politics in the early 1990s, will help enrich the debate on the nature of the political change that Italy has experienced in the past seventeen years.

Keywords

Transition; Italy; Political Change; Italian Politics; Italian Democracy

\section{Introduction}

In a recent article James Newell (2009), evaluating the implications of the Italian 2008 general election for the Italian transition, argues that the concept of 'transition' should no longer be used to try and explain the changes in Italian politics since the early 1990s, for several reasons: the length of the transition (at 17 years) is too long to be adequately captured as a transition; it remains uncertain what it is the Italian regime is supposedly in transition towards; one can not tell whether a country is in transition until it is completed; ongoing discussion about fundamental rules of the constitutional game does not necessarily betoken a transition; and, finally, the outcome of the 2008 elections does not (contrary to the views of some authors) suggest that initial expectations about system performance created by changes to the 
party system following the elections have been fulfilled. He concludes therefore that 'as conventionally understood the term is now best abandoned in analyses of Italian politics', implying, further more, that the Italian transition was, in fact, the 'man who never was' (Newell, 2009, 410).

This position may be controversial with, and contested by, some Italianists. It is a position, however, with which this author, who has made analogous points (e.g. Bull 2006a, 2006b; Bull and Rhodes 2009b), agrees. ${ }^{1}$ It is an important argument which raises several issues in need of further elaboration, if there is to be a wider debate on whether or not the notion of the 'Italian transition' should be discarded. ${ }^{2}$ The purpose of this article is to explore these issues and hopefully stimulate such a debate. Four such issues arise.

First, if we abandon transition as a useful concept for the analysis of Italian politics, the question arises as to how we regard the wealth of research that has been conducted on Italy since the early 1990s in this vein. The issue is not just whether the concept has applicability today (which is Newell's point) but whether or not it had or has had applicability at any point in time since the early 1990s, and if not why not. Second, if, the answer is that it has not had useful applicability at any point in time since the early 1990s, then it surely behoves us as Italianists to explain why it was adopted, why we got it wrong, and even why it took 17 years for us to discover this. Third, the 'Italian transition' made Italy something of an anomalous case. If we are now suggesting that it was not, in fact, anomalous, are there nonetheless any lessons which we might draw from its apparent anomaly during this period? Fourth, if the concept is not an applicable category to analyse Italy, how are we to categorise the Italian case today? Can we, in other words, ditch transition without losing entirely the 'special' or 'watershed' nature of the 1990s? 
This article, in short, attempts to build on Newell's argument through a reflection on the academic treatment of the Italian transition during the 1990s, why it was problematic, and what might be done both to improve our understanding of the concept and its relevance (or not) to the Italian case. The first section summarises the dramatic changes of the early 1990s and the development of the notion of the Italian transition. The second section analyses more closely the maintenance of this idea despite its problematic nature. The third section outlines how the concept of transition needs to be taken more seriously, and what this might involve, and the fourth section makes a prima facie case against using transition to understand the Italian case since the early 1990s, and suggests an alternative approach. The conclusion returns to the four questions raised in this introduction, and argues that, while the concept of transition should be set aside to understand the Italian case, we should not, at the same time, lose sight of the exceptional nature of the developments of the early 1990s. The article provides a springboard for further research on the Italian case as well as on the possibility and nature of second (or 'secondary') transitions occurring in advanced democracies.

\section{The Italian Transition: Birth of a 'Myth'}

It is not necessary (for a publication in an Italianist journal) to dwell long on the events of the early 1990s. ${ }^{3}$ Unexpected and unpredicted, Italian politics underwent a dramatic and unprecedented upheaval. The ruling parties electorally and organisationally disintegrated, the two main parties of opposition (communists and neo-fascists) transformed themselves into different parties by shedding their ideological identities, the party system underwent a meltdown and transformation, the electoral system was reformed from a pure PR system to one based on a mix between 
proportional and majoritarian elements. New political parties and alliances emerged, as the party system underwent bipolarisation into two broad and unwieldy coalitions, of the centre left and centre right. A decade of political change followed, involving, in some shape or other, all aspects of the Republic: institutions, parties, voting behaviour, policies, state regulation and the political class.

Most importantly, a revision of the constitutional settlement came firmly onto the agenda, and in 1997, the Bicamerale, a commission on constitutional reform, began its work. True, the following year the Bicamerale failed, its project for a new constitution being sunk in parliament by Berlusconi announcing his party's withdrawal of support, but this did not end the season of constitutional reform. In 1999-2000, the centre left government carried through a change to Title $\mathrm{V}$ of the constitution (relating to regional devolution), and, following this, Berlusconi, as Prime Minister after 2001, began his own attempt to achieve constitutional reform with a project that was passed by parliament in 2005 but subsequently defeated by referendum in June 2006. Despite these setbacks constitutional reform has remained, since the referendum, firmly on the agenda of Italian politics.

More important than the events themselves, from the perspective of this article, were the reactions to them of Italianists. It could be argued that we were illprepared for this dramatic turn of events, for, even though the conventional wisdom about Italian democracy was that it was an anomalous case, the bulk of the literature until the early 1990s had been focused on explaining why, amidst the instabilities, so little changed, and was likely to change, in Italian politics. Even on the cusp of the dramatic downfall of the Christian Democrat (DC) 'party regime', publications appeared explaining the persistence of this party and, by implication, its continuing dominance (e.g Leonardi and Wertman 1989; Tarrow 1990; Hine 1993), if not lauding 
the state of Italian democracy itself (LaPalombara 1988). It is not surprising, therefore, that the dramatic changes of the 1990s took us off our guard. ${ }^{4}$

The immediate response was an inevitable curiosity in revisiting the DC 'party-regime' and reflecting on why Italianists had failed to predict what would suddenly occur, not that criticism of this failure was widespread (Bull 1996). Yet, as the apparent scale of the political changes became apparent, Italianists became quickly absorbed by the trajectory of change: how it could be captured and explained and where it might be leading. It seemed evident that, after fifty years of stagnation under DC rule, the polity was not only undergoing the most dramatic crisis since its founding but was on the verge of a veritable regime change, and for this reason 'transition' appeared to be the best concept to capture what was going on. Pasquino's $(1997,34)$ view captured the mood:

'There is no doubt that the Italian political system has been undergoing a transition for some time...It is a peculiar transition from a democratic regime, correctly identified as partitocrazia (one dominated by political parties), to another regime, more or less equally democratic'.

Whatever the continuities with the past, the general consensus was that what was happening in Italy constituted the most dramatic break with the past since the fall of Fascism and the birth of the Republic. In the heady political atmosphere of the early 1990s, when everything seemed possible (and so much was desirable), maybe it seemed logical to transpose the notion of 'transition' to the Italian case. At a general level it conjured up notions of the transitions from authoritarian rule (e.g. Feltrin 1996; Massari 1996), except this would be a transition between two democratic regimes, the new which was expected to be an improvement on the old. It was captured in both journalism and academe by the notion of a transition occurring 
between a 'First Republic' and 'Second Republic'. Once this assumption (of a transition) took hold, it logically followed that political developments tended to be seen through the prism of an expected 'end-point'. Italy was, in short, going somewhere. It just needed to 'arrive'.....which it subsequently failed to do.

\section{A (Very) Long Transition: Maintenance of the 'Myth'}

This problem of non-arrival was not, for the transitional approach, a problem in the short-term, but became more difficult as time went on. Indeed, the failure of the Bicamerale suggested that, if this were a transition, it might be long and messy rather than short and neat, for, if the transition began in the early $1990 \mathrm{~s}^{5}$, it meant that, by the early Millennium, Italy had already been 'in transition' for nearly a decade. If a transition was 'the interval between one political regime and another' (O'Donnell and Schmitter 1986, 6), was it still feasible to describe Italy as being 'in transition'? Were transitions not meant to be extraordinary and intense phases in the development of political systems, as confirmed in the political science characterisation of transitions from authoritarian rule? Morlino (1994, 573-5), for example, defined a democratic transition as 'that fluid and confused period when new democratic structures are about to emerge', followed by installation which 'is characterized by the formation of new institutions and procedures, as well as by the presence of all the other features intrinsic to a democratic regime.'

This extraordinary nature is reinforced in looking at the phase which follows that of (a first, or 'prime', democratic) transition: democratic consolidation, which is a much longer and more protracted affair than transition. The process is not inevitably progressive and linear, and the most common time frame (supported by empirical analysis) is 10-12 years, although some authors speak of a generation. Was it feasible, 
therefore, to continue to speak of a transition that would be as long as, if not longer than, the process of democratic consolidation? Pasquino $(1994,45)$, in reference to the Italian transition, argued that, 'the length of the [transition] is highly variable...it should not exceed a decade. No political system can remain in a state of flux for such a long period of time.'

Perhaps for this reason, after the failure of the Bicamerale and especially with the turn of the Millennium, one can detect, over the subsequent decade, a divide in the approach to the transition. Some authors (wittingly or unwittingly) solved the problem of the length of the transition by effectively hastening it along. We had either already arrived at the 'Second Republic', or the transition itself was the Second Republic, or, for others, the 'Second Republic' had, in fact, been and gone, and we were now in a so-called 'Third Republic' (see, for example, Calise 2006; Massetti 2009). Meanwhile, for those still wedded to the notion of the continuing transition, a litany of adjectives crept into the literature, which seemed to 'qualify' or 'make special' the particular Italian transitional experience: 'long', 'never-ending', 'infinite', 'faltering', 'stalled' and so on. ${ }^{7}$

Finally, there were those authors who attempted to use political science concepts and comparative politics to develop more rigorously the transitional approach in relation to Italy. ${ }^{8}$ The best examples of these efforts are the work of Allum and Newell, Fabbrini and Pasquino. Allum and Newell (2003, 188), drawing partly on Juan Linz, located the transition as being in a sixth phase, 'the stalled transition' (and one that 'remains incomplete'). This occurred when the fifth phase (in Linz's words, ‘breakthrough...[when]...non-incumbent contenders succeed in piercing or bypassing structures of accountability in order to capture the prize of incumbency' - Berlusconi in this case) failed to produce 'institutional change 
allowing for a resynchronization of the system...'. Fabbrini (2000, 17 \& 234-6; and see also 2006), redefined 'transition' as a process which may or may not result in regime change, and then explained why the Italian case had failed to do so, at the same time as speculating on the possible 'institutionalisation' of a hybrid regime (neither 'consensual' nor 'majoritarian'). Pasquino (2001, 316-7) argued, on the basis of a systems approach derived from David Easton, for the idea of an 'infinite transition' in the Italian case, an adjective he preferred to 'incomplete', since the latter would give a false sense of 'knowing in advance the point of arrival, of completion', although he remained clear that it was 'incomplete' and what made it so: 'The incompleteness of the transition lies precisely in the non-achievement of the reformers' objective ['the construction of a different regime'], in the contradictory nature of many proposals, in the conflicting nature of many solutions' (Pasquino 2001, 318).

These authors appeared to have been influenced by two factors. The first was comparison, and specifically that of the French case of the transition between the Fourth and Fifth Republics of 1958-62. Allum and Newell (2003, 186-7) argued that the Italian case should be considered in this category, Fabbrini $(2000,210)$ described it as 'the only occurrence that is comparable with the Italian experience', and Pasquino $(2007,283)$ noted that 'From the very beginning of the Italian transition, my analytical and political suggestion has been to look at the French transition from the Fourth to the Fifth Republic. ${ }^{9}$ The second was the need for an element of theoretical or conceptual novelty because of the unusual nature of the Italian case. Pasquino (2000, 203), in fact, argued that 'the Italian transition presents so many peculiarities that it must be treated as a fundamentally anomalous case. ${ }^{10}$ Yet, both these sources of influence were potentially problematic. 
On the one hand, the comparison with the French case was evidently tempting, especially as the core substance of the 'transitions' could be said to have been similar: the shift from political systems which had not until then enjoyed alternation in governments to systems which did. Indeed, Allum and Newell $(2003,186-7)$ used as an example Juan Linz's (1978, 87-8) concept of 'requilibration' which the author had developed as an example of transitional change 'within the genus democratic', using the French transition from the $4^{\text {th }}$ to the $5^{\text {th }}$ republics (1958-62). Yet, applying it to the Italian case of the 1990s was not unproblematic, since 'requilibration' was a concept that referred to change in a democratic regime which was threatened by collapse: 'Requilibration of a democracy is a political process that, after a crisis that has seriously threatened the continuity and stability of the basic democratic political mechanisms, results in their continued existence at the same or higher levels of democratic legitimacy, efficacy and effectiveness' (Linz 1978, 87). There are variations in this process but all occur during the breakdown process, during which 'reequilibration' is a means of saving democracy. In the Italian case of the 1990s, the continued existence of the Republic as a democracy was never at stake (and on this there was widespread consensus).

On the other hand, the dangers of treating the Italian case as an anomaly were potentially to grant Italy a form of 'special status', divorcing it from the mainstream of comparative political analysis (i.e. comparison with other countries). ${ }^{11}$ This might be feasible for a short intense interlude in a country's political development, but to use it to frame an extensive time-frame could be problematic. Of course, this would not rule out using a potentially anomalous empirical case to improve or refine concepts or theories, as long as the dangers of generating confusion through such an exercise could be avoided. For example, there was an evident problem in the idea of a 
country having been 'in transition' but not producing a regime change when the accepted definition of a 'transition' is the interval between two regimes. Did not redefining 'transition' to make the Italian experience fit stretch the concept too far to be credible or useful to political science? An analogous argument might be made about the concept of a 'stalled transition': if it appeared to be unending, what did it signify for a political system in terms of its nature and potential for comparison with other systems? And if the grounds of 'incompleteness' of the transition were to be the continued existence of intentions of reformers to achieve a constitutional revision, but their failure to do so, the problem was that reformers had been attempting to do this since as long ago as 1983 (when Bettino Craxi launched the idea of the so-called 'Great Reform'). One might also think of other countries which, on the basis of unfulfilled reformist intentions and the debate surrounding them, might therefore qualify, according to this reasoning, for 'transitional' status.

If these approaches had one thing in common, it was that they did not question the assumption that Italy was in transition; on the contrary, they appeared to start with this assumption, developing the interpretative range of the concept so ensuring it still applied to the Italian case. ${ }^{12}$ The transitional approach, then, was successfully maintained throughout the first decade of the Millennium. Indeed, in many respects it became pervasive insofar as the persistence with the notion often made it a starting point or paradigm for the analysis of various specific aspects of the political system (elections, parties, leadership, institutions, events) or even the political system itself (for a few examples: Ceccanti and Vassallo 2003; Paolucci 2006; Carbone and Newell 2008; Massetti 2009; Edwards 2009; Pasquino 2002). ${ }^{13}$

Yet, at the same time, as evident from above, this was pervasiveness through diversity rather than unity. Indeed, it is more accurate to speak of transitional 
approaches rather than an approach. This diversity stemmed from the sheer difficulties presented by the Italian case, which were neatly summed up by Allum and Newell (2003 188-9). Accepting the classical definition of 'transition' and concluding that in the Italian case there had been 'no clear break with the essentials of the 1948 constitution', they argued nevertheless that, 'judged according to less exacting criteria, focusing less on formal constitutional change than on the distribution of institutional power among contenders and on the political system's mode of functioning broadly defined, a case can be made that a transition of sorts has taken place'. ${ }^{14}$ To quote Newell (2000 185), 'the "Second Republic" may yet be unborn; the "First Republic" is, equally obviously, dead' (which has echoes of the institutionalisation of Fabbrini's hybrid).

In other words, if the Italian case appeared to be difficult to classify it was because it had all the hallmarks of a transition but apparently without the (regime) outcome necessary to define it as having been completed, and with the prospect of its completion apparently having receded. ${ }^{15}$ In short, as Pasquino $(2000,204)$ noted, in the Italian case it remained unclear 'how much and what kind of transition' had been taking place. Perhaps none at all? Should Italy be freed from the transition, and if so how?

\section{Taking Transition Seriously}

Perhaps it is less a matter of freeing Italy from the transition than of developing the concept of a 'second (or secondary) transition' and then seeing whether it can or can not be applied to the Italian case. This is essential because, as Pasquino $(2001,313)$ has noted, transition is an explanatory category of a transition from authoritarian rule to liberal democracy: there is no theory to account for transitions inside democratic 
regimes. Transitions, in political science, refer to inter-regime and not intra-regime changes. Yet, this has not prevented Italianists adopting the word for an expected intra-regime change, and they are not alone. The French experience of 1958-1962 has already been noted, and Spain has been subject to similar debate (e.g. Field, 2009). ${ }^{16}$ This suggests that there may be examples of change inside democracies that either are, or appear to be, or have the potential to be, so wide-ranging that they may constitute a change from one type of democratic regime to another, resulting in the use by political scientists of a term which seems best able to capture this sense of change. If so, what are the sort of issues that need to be addressed in order to advance such a theory ${ }^{17}$

First, the question arises as to whether or not such levels of political change are possible in advanced democracies, when much of the political science literature on the consolidation of democracies is predicated on declining levels of fundamental change over time? Research by Morlino (1998), however, suggests that such levels of political change are possible. He argues that the origins of profound crises and changes lie in the particular manner in which a democracy is consolidated. $\mathrm{He}$ conceives democratic consolidation as a two-way process, bottom-up ('legitimation') and top-down ('anchoring'), and it is the particular combination of these two that will shape both the consolidation process and its outcome i.e. the particular type of consolidated democracy that results. He argues that in countries where civil society is, in the initial stages of democratic consolidation, weakly developed and where legitimacy of the system remains low or limited (or, in his words, 'exclusive'), political parties can fill a key role in 'anchoring' society to the political system. However, this process of top-down anchoring can build in the potential for later crisis and change because it can impose rigidities, distortions, resistance of vested interests 
and lower capabilities of adaptation. Consequently, when civil society matures and the anchors of control are undermined, the magnitude of political crisis and change can be much greater than that expected or predicted in much of the literature on democratic consolidation. He refers to this as 'the paradox of consolidation: as a tendency, in the longer run a stronger consolidation (with low legitimation) may be at the origins of a deeper crisis' (Morlino 1998, 273).

Second, if, therefore, changes of this sort are possible, then, we need to be able to identify at what point a change of a transitional nature may, in fact, have occurred. $^{18}$ This requires a clear definition of regime and classification of (democratic) regimes, because, if we accept that a transition is 'the interval that elapses between one regime and another' (Pasquino 2000, 202), then, in cases of 'second transitions' the definition of 'regime' and classification of democratic regimes becomes all the more important. In 'first' transitions, this may not be so important because the difference is between an authoritarian and a democratic or hybrid regime, and the transition is judged accordingly. But in the case of 'second transitions' between two democratic regimes, the definition of regime and classification of democratic regimes becomes essential for anyone faced with the empirical task of assessing whether or not a democratic regime has undergone a transition from one type to another. Democratic regimes may be classified according to their institutional arrangements or their broad mode of functioning (or a mix of both), and it is essential, in order to test transitional change, that changes in the political system or the sub-systems of a political system are evaluated against a classification of (democratic) regimes. ${ }^{19}$ This is obviously a difficult task in view of the fact that political change is a complex, multi-faceted and cumulative process, and 
that sub-system changes may or may not contribute to broader systemic or regimelevel change. ${ }^{20}$

Third, if we can identify when a transition has occurred between two democratic regimes, it may allow us to identify the defining characteristics of 'second transitions' and therefore assess whether or not they can be defined in such a way as to make it easier to compare them. 'First' transitions have been characterised in relation to the transition's origins/starting point, character, duration and the conditions of completion (e.g. Morlino 1994, 573-5; Linz et al. 1995, 78), and the task would be to see whether a similar exercise could be conducted for 'second transitions.'

In short, more work is needed to define and characterise 'second transitions'. When completed, a more rigorous empirical application to the Italian case (as well as others) could then be made. However, it is worth, in the last part of this article, returning to the Italian case to anticipate the likely outcome of such an empirical exercise.

\section{Freeing Italy from the Transition}

We might pose and attempt to answer tentatively three questions in order to assess whether or not Italy has been or is in transition. We will then consider an alternative interpretation of the period since the early 1990s.

First, if a 'second transition' constitutes the interval between two democratic regimes, was there a passing of the Italian 'First Republic' which thus marked the beginning of a transition? On the one hand, there was clearly a crisis of the old regime in the early 1990s, a calling into question of the existing constitutional arrangements and the emergence of a consensus that saw constitutional and transition to a Second Republic as essential. On the other hand, 'there was not a true collapse of the 
preceding regime...of its norms and institutions. A clear break with the past did not occur... and there was no politico-constitutional trauma that rendered indispensable the construction of a new regime' (Pasquino 2000, 203; and see Allum and Newell 2003, 188-9). Moreover, the calling into question of the existing constitutional arrangements, although very prominent, was in keeping with a long tradition of attempts to reform the constitution. This can surely be regarded as a necessary but not sufficient condition for a transition to occur. Indeed, the prominence and protraction of that sort of debate may make the politics of a country distinctive, almost anomalous, but that is a different matter to a country actually being in transition (Bull and Newell 2009). In short, while this is not in anyway conclusive (because 'regimes' can 'pass' in different ways), there is considerable doubt as to whether or not the conditions for the commencement of a transition were in place in the early 1990s.

Second, if a transition is the interval between two regimes, and a transition's most important defining characteristic is therefore a 'point of arrival', has Italy arrived at a new regime? Answering this question will, of course, depend on one's definition of 'regime', the characterisation of the existing Italian regime and an assessment of whether or not a new regime has emerged. As noted above, there are those who argue that a change in regime (if not two) has occurred, although one might question to what extent these authors base (or even claim to base) their arguments rigorously on 'regime change', rather than being used for effect to reinforce the argument about how much change the Republic has experienced. ${ }^{21}$ The broader consensus, however, is that, even assuming one can identify a 'point of departure', Italy has not yet reached a 'point of arrival'.

Third, assuming that a 'departing' point could be identified in the early 1990s but not an 'arrival' point, would it be possible argue that Italy is currently in 
transition? With the political upheaval that has occurred and ongoing attempts at constitutional and institutional reform, a prima facie case might be made that this is evidence of a transition underway. However, it is difficult to see how this would be feasible, even if the characteristics of 'second transitions' were to be fairly clearly defined, simply because the existence of a transition would be dependent upon a 'regime' change (however that is defined) having occurred. In other words, a transition could only be definitively identified once it had taken place, and this means that it is inherently problematic, if not a misnomer, to speak of a country being 'in transition'. Anything short of the 'point of arrival' as a defining characteristic would risk the obvious: that a transition identified by other characteristics might then fail to produce a regime change and could effectively go on forever, which is precisely the risk in assessing the Italian case today. ${ }^{22}$

Fourth, if constitutional reform and a clear 'regime' change were to occur in the future, would this indicate that, all along, the 'myth' was not, in fact, a myth, that a transition had been underway and was now completed? Depending, of course, on how the characteristics of 'second transitions' were to be defined, it remains questionable as to whether it would help an understanding of contemporary Italian politics to dub an entire twenty (or more) year period in its post-war political history as a 'transition'. It would make more sense to an understanding of Italy's political development to date any transition from the date that the successful effort began in earnest, rather than dating it back through an entire season of political development (which would become an historical context for the transition).

Fifth, if all of this is the case, what has been happening in Italy since the early 1990s, and is there anything at all 'exceptional' in the political change it has experienced? Put another way, if much of the literature of the past decade has 
implicitly assumed or explicitly argued that Italy has been in transition (and therefore has a distinct 'status'), is there a danger, in now questioning this, of throwing out the baby with the bathwater i.e. failing to capture those elements or aspects that might well need emphasis as exceptional in nature? Perhaps the answer to this question lies in the temporal unit used to analyse the Italian case, which can provide the focus for the development of an alternative approach. ${ }^{23}$

An approach which begins with a presumed 'point of departure' in the early 1990s and then analyses today's situation as the current 'end-point' (since there has not yet been a 'point of arrival') becomes more difficult as time goes on: the temporal unit of analysis becomes ever longer, and maintaining an argument that something exceptional is occurring becomes increasingly difficult. An alternative would be to focus on the early 1990s as a watershed moment but not necessarily in terms of setting in motion an entire period of political change. In fact, the main changes of the early $1990 \mathrm{~s}$ concerned the political parties, whose role is fundamental to understanding this argument (Bull and Newell 2005, ch. 1).

The important point to note is that the political parties were the victims rather than the vehicles of the dramatic changes of the early 1990s, the sources of which were various, but notably in pressures emanating from two 'fault lines' running through the Italian system: the ramifications of the end of the Cold War and the demands of European and international economic integration. In this context, the exposure of systemic political corruption by Italian magistrates acted as the trigger for a crisis which was profound and protracted largely because the existing parties organisationally and electorally disintegrated, and the party system underwent a form of meltdown and transformation. This meant that parties, essential everywhere to the functioning of advanced liberal democracies, temporarily were unable to fulfil their 
roles: indeed, at the height of the crisis the parties were unable to sustain party government and the Italian President had to resort to appointing 'technocratic' governments. However, once the 'party political sphere' began to reformulate and reassert itself, it began inevitably to claw back its control over reform and the management of change. Many expected, with the dramatic turnover in parties and the political class, and with public pressure for change, that a comprehensive reform of the political system would follow. Yet, those expectations overestimated the capacities and the will of so-called new parties and politicians to secure such reform. Four factors played a role in reversing expectations.

First, the party political arena itself remained in turmoil for many years (and is still evolving), thus failing to provide the levels of stabilisation that might provide a strong foundation for a radical programme of institutional reform. Second, at the same time, the party system quickly established its own new dynamic in which party strategies, interests and vetoes became dominant, especially as the pressures created by the sense of crisis and urgency to achieve reform declined. Third, the partypolitical sphere was not independent from broader social and economic interests, many of which offered stiff resistance to political-economic reforms which might accompany institutional reform. Finally, the turmoil in party politics threw up a new party (Forza Italia) and politician (Silvio Berlusconi), whose dominance in politics and whose monopoly over the media had a significant (negative) influence on the reform debate in two interrelated ways: first, by causing fierce opposition to several reforms, because perceived to be shoring up Berlusconi's personal interests; and second, by causing other parties to hesitate in their quest to strengthen party government and the power of the executive while Berlusconi and his party remained the dominant force in Italian politics. In short, the turmoil in party politics that 
occurred in the 1990s generated high expectations that comprehensive reform of the political system would be achieved, but those expectations were not subsequently met.

This type of approach to the Italian case fits with an historical institutional perspective which views change in complex political systems usually occurring either by way of a 'punctuated equilibrium' (long periods of stability interrupted by sudden, often dramatic, shifts, before path-dependent development resumes) or via multiple processes that modify the nature of the existing order but rarely overturn it (see, for example, Thelen 2003 and Streeck and Thelen 2005). As Bull and Rhodes (2009b, 6) argue, 'The equilibrium of Italy's post-war system was clearly "punctuated" by the political and economic upheavals of the early and mid-1990s. But what followed has been less of a "transition" to something new, and more of a post-crisis process of institutional (re-) stabilisation and negotiated change in which the "new" (or at least substantial parts of it) looks remarkably similar to the "old",

This can be characterised as a catalogue of different processes of institutional change: institutional 'drift' (gradual and sometimes unplanned adaptation of institutions and policies); institutional 'layering' (the creation of new policies or institutions without eliminating the 'old'); institutional 'revision' (formal reform, replacement or elimination of an existing policy or institution); and institutional 'exhaustion' (the perverse persistence of an institution whose raison d'être has been lost but which cannot, for political reasons, be reformed). In short, the Italian case can be understood in the context of 'multiple forms of institutional and negotiated change ... [in which 'institutional layering' has probably been dominant] characterised by path-dependent evolution, with no assumption that an end-point is in sight' (Bull and Rhodes 2009b, 12). 
This argument, while not necessarily comprehensive in its explanatory power, is presented here as an example of how an alternative to the transitional approach can be developed. In brief, and picking up on popular words used to describe this period, it states: there was a crisis (and changes that went with it), but there was no transition.

\section{Conclusion: Freeing Italianists from the Transition}

This article has aimed to stimulate a wider debate on the manner in which the Italian case has been treated since the early 1990s, and to conclude this task we may usefully turn to answer the four questions posed in the Introduction.

First, regarding the value of having used 'transition' as an explanatory category of change since the early 1990s, it might be argued that its use over the past 17 years has taken on the characteristics of a 'homonym' - a single term expressing multiple distinct concepts and causing 'collective ambiguity' (Sartori 1984). This is not just an issue of terminological difference but rather the transposition of an important political science concept into a context for which it was not designed. It could be argued that the manner in which the term has been used has not helped us to understand what has been happening in Italian politics since the early 1990s, and does little or nothing to illuminate the situation today. Moreover, even if a regime change were to occur in the future, it would not be a useful concept in order to understand the politics of the last two decades. This is not to question the value of the research into political change in Italy in this period. On the contrary, much of it has been of fundamental importance, especially the use of the idea of 'transition' to analyse subsystem elements such as individual political parties, the party system, the electoral system etc. These sub-system analyses are, however, best not located within a teleological framework which assumes that Italy is in transition towards a new 
'regime' which will be completed at some point in the future. Indeed, if we remove any assumption of an 'end-point' and effectively free Italianists from the transition, it will surely enrich our quest to evaluate the political change that Italy has experienced in the period since the early 1990s.

Second, in terms of explaining why 'transition' was (in this author's view, mistakenly) adopted, it could be argued that the events of the early 1990s in Italian politics and the interpretative demands they posed dealt a form of 'double blow' to Italianists. In the first place, we failed to predict the dramatic changes that occurred in the early 1990s (indeed, most analyses were predicated on the opposite assumption). We were then content (with journalists and politicians) to sail on what looked to be a promising sea, only subsequently to find the tide going out and our analyses 'beached'. Left by comparativists to deal with our own case, we became too hitched either to novelty or to the historical model provided by Italy's neighbour: it all looked so French....yet, not for the first time, the Italian case flattered to deceive. And while it is true that serious lines of enquiry were carried out, the persistence with a basic, increasingly problematic assumption bred a rising degree of novelty or inventiveness in approaching the Italian case, with perhaps insufficient attention to the need for a more detailed conceptual and theoretical exercise before empirical analysis. ${ }^{24}$

Third, such an exercise might, of course, involve extrapolating from the apparently anomalous case in front of us. Indeed, to argue that Italy is or is not in transition today, we need to do more than engage in just an empirical argument about the case, for fear that any new position might also turn out to be problematic or ephemeral, if not supported by a clear conceptual idea of a 'second transition'. The work required for this might, in fact, conclude that the notion of a 'second transition' is not, in fact, a useful conceptual tool for understanding high levels of political 
change in advanced democracies, and should not be developed. However, the key point here is that the concept of a 'second transition' should either be treated seriously as a concept and then applied empirically, or be dispensed with as a term of use for describing cases such as the Italian one.

Fourth, since the outcome of such an exercise (even if it were to produce a useful concept called a 'second transition') is likely (in this author's view) to exclude the Italian case, it is important to engage with the debate on Italy and cast doubt on what appears to have become a conventional wisdom that Italy is in transition. At the same time, it is important not to dispense entirely with the idea that something 'special' happened in Italian politics in the early 1990s. This can be done by a greater focus on that specific period, without linking it to an entire temporal unit of change stretching over seventeen years. If not, there is a danger of us throwing out the baby with the bathwater before we are ready to do so: political historians fifty years hence might see the 1990s either as a significant watershed in the country's political history, or, alternatively, as little more than a 'blip' in the country's political development. For Italianists today it is too early to tell, but most remain convinced that something exceptional occurred in Italian politics during the 1990s and it is therefore important that, in rejecting transition as an explanatory category of change, the watershed moment is not thereby lost from view... at least yet.

\section{References}

Allum, F., and J. Newell, eds. 2003. Introduction (Aspects of the Transition). Journal of Modern Italian Studies 8 (2) Summer: 182-96.

Armony, A. C., and H. E. Schamis, 2005. Babel in Democratization Studies. Journal of Democracy 16 (4): 113-28.

Bardi, L. 2009. Electoral Change and its Impact on the Party System in Italy in Bull and Rhodes 2009a: 55-76. 
Bull, M. J. 1996. The Roots of the Italian Crisis. Southern European Society and Politics, 1 (1) Spring: 131-37.

Bull, M. J. 1997. New Research into the Democratisation of Italy', paper presented to 'New Research on Modern Italy', Association for the Study of Modern Italy, Annual Conference, Italian Cultural Institute, London, 21 November.

Bull, M. J. 1998. Democratisation and Explaining Systemic Change in Italy. Paper presented to European Consortium of Political Research, Joint Sessions of Workshops, University of Warwick, 23-28 March 1998.

Bull, M. J. 2006a. Evaluating the 'Difficult Democracy' since the Early 1990s: the Inadequacy of Existing Theoretical Approaches (and their Empirical Applications) to the Italian Case. Convegno Nazionale, Società italiana di scienza politica 12-14 September.

Bull, M. J. 2006b. The Limits of Democratisation Theory to the Italian Case. Paper presented to Department of Politics, University of Hull, 11 November.

Bull, M. J., and J. L. Newell. 1997. Party Organisations and Alliances in the 1990s: A Revolution of Sorts in Bull and Rhodes 1997: 81-109.

Bull, M. J., and J. L. Newell. 2005. Italian Politics. Adjustment under Duress. Cambridge: Polity Press.

Bull, M. J., and J. L. Newell. 2009. Still the Anomalous Democracy? Politics and Institutions in Italy. Government and Opposition, 44, 1, January: 42-67.

Bull, M., and M. Rhodes, eds. 1997. Between Crisis and Transition: Italian Politics in the 1990s. London: Frank Cass.

Bull, M., and M. Rhodes, eds. 2009a. Italy: A Contested Polity. Special Issue, West European Politics, 30, 4, September.

Bull, M., and M. Rhodes. 2009b. Introduction - Italy: a Contested Polity in Bull and Rhodes 2009a: 1-13.

Caciagli, M., F. Cazzola, L. Morlino, and S. Passigli, eds. 1994. L'Italia fra crisi e transizione. Bari-Rome: Laterza.

Calise, M. 2006. La terza Repubblica: partiti contro presidenti. Bari: Laterza.

Ceccanti, S., and S. Vassallo. 2003. Come chiudere la transizione. Cambiamento, apprendimento e adattamento nel sistema politico italiano. Bologna: Mulino.

Carbone, M., and J. L. Newell. 2008. Toward the End of a Long Transition? Bipolarity and Instability in Italy's Changing Political System. Politics 28 (3): 38-49.

Carbone, M., and J. L. Newell. 2009. Editorial: Italy, the Never-ending Transition and Political Science. Bulletin of Italian Politics 1 (1): 1-5. 
Collier, D. and S. Levitsky. 1997. Democracy with Adjectives: Conceptual Innovation in Comparative Research', World Politics 49 (2): 430-51.

Edwards, P. 2009. 'Veniamo da lontano e Andiamo lontano': the Italian Left and the Problem of Transition. Bulletin of Italian Politics 1 (2): 211-32.

Fabbrini, S. 2000. Tra pressione e veti. Il cambiamento politico in Italia. Rome-Bari: Laterza.

Fabbrini, S. 2006. The Italian Case of a Transition within Democracy. Journal of Southern Europe and the Balkans, 8 (2): 145-61.

Fabbrini, S. 2009. The Transformation of Italian Democracy. Bulletin of Italian Politics 1 (1) Summer: 29-48.

Feltrin, P. 1996. Transizione di regime e possibili scenari di consolidamento: un modello interpretativo. Associazione per gli studi e le ricerche parlamentari, Quaderno 6 Seminario 1995.

Field, B. N. 2009. A 'Second Transition' in Spain? Policy, Institutions and Interparty Politics under Zapatero (2004-8). South European Society and Politics. 14 (4): 37997.

Gilbert, M., and G. Pasquino, eds. Italian Politics: the Faltering Transition. Oxford: Berghahn.

Grilli di Cortona, P. 2007. Il cambiamento politico in Italia. Dalla Prima alla Seconda Repubblica. Rome: Carocci.

Hine, D. 1993. Governing Italy. The Politics of Bargained Pluralism. Oxford: Oxford University Press.

Lange, P., and S. Tarrow, eds. 1979. Italy in Transition: Conflict and Consensus, West European Politics, Special Issue 2 (3) October.

LaPalombara, J. 1988. Democracy, Italian Style. New Haven: Yale University Press.

Leonardi, R., and D. A. Wertman. 1989. Italian Christian Democracy: the Politics of Dominance. New York: St. Martin's Press.

Linz, J. (1978). The Breakdown of Democratic Regimes: Crisis, Breakdown and Reequilibration. Baltimore: Johns Hopkins Press.

Linz, J., A. Stepan, and R. Gunther. 1995. Democratic Transition and Consolidation in Southern Europe, with Reflections on Latin America and Eastern Europe. In R. Gunther, P. N. Diammandouros, and H.-J. Puhle. The Politics of Democratic Consolidation. Southern Europe in Comparative Perspective. Baltimore: John's Hopkins University Press: 77-123. 
Massari, O. 1996. Italy's Postwar Transition in Comparative Perspective. In G. Pridham and P. G. Lewis, eds. Stabilising Fragile Democracies. Comparing New Party Systems in Southern and Eastern Europe. London: Routledge: 126-44.

Massetti, E. 2009. The Sunrise of the Third Republic? The evolution of the Italian party-system after the 2008 general election and the prospects for constitutional reform. Modern Italy 14 (4): 485-98.

Morlino, L. 1994. Democratic Consolidation: Definition and Models. In G. Pridham, ed. Transitions to Democracy. Comparative Perspectives from Southern Europe,

Latin America and Eastern Europe. Aldershot: Dartmouth 1995: 571-89.

Morlino, L. 1998. Democracy Between Consolidation and Crisis. Parties, Groups, and Citizens in Southern Europe. Oxford: Oxford University Press.

Morlino, L. 2009. Transition from Democracy to Democracy: Is it Possible in Italy? Bulletin of Italian Politics. 1 (1): 7-27.

Newell, J. L. 2000. Parties and Democracy in Italy. Aldershot: Ashgate.

Newell, J. L. 2004. Interpretative approaches and the study of Italian politics. Modern Italy 9 (2), November: 247-61.

Newell, J. L. 2009. The man who never was? The Italian transition and 2008 election. Journal of Modern Italian Studies 14 (4): 395-412.

O'Donnell, G., and P. Schmitter. 1986. Tentative Conclusions about Uncertain Democracies. Vol. 4 of G. O'Donnell, P. Schmitter and L. Whitehead, eds. Transitions from Authoritarian Rule: Prospects for Democracy. Baltimore: John's Hopkins University Press.

Paolucci, C. 2006. The Nature of Forza Italia and the Italian Transition. Journal of Balkan and Near Eastern Studies 8 (2): 163-78.

Pasquino, G. 1994. Shaping a Better Republic? The Italian Case in Comparative Perspective. Estudios/Working Paper 1994/62, November, Madrid, Instituto Juan March de Estudios e Investigaciones.

Pasquino, G. 1997. No Longer a 'Party State': Institutions, Power and the Problems of Italian Reform. In M. Bull and M. Rhodes, eds. Crisis and Transition in Italian Politics. London: Frank Cass: 34-53.

Pasquino, G. 2000. La transizione a parole. Bologna: Mulino.

Pasquino, G. 2001. Teorie della transizione e analisi del sistema politico: il caso italiano. Rivista Italiana di Scienza Politica 2, August: 313-27.

Pasquino, G. 2002. Il sistema politico italiano. Autorità, istituzioni, società. Bologna: Bononia University Press. 
Pasquino, G. 2007. Italian Politics: no improvement in sight. Journal of Modern Italian Studies 12 (3): 273-85.

Robertson, D. 2002. A Dictionary of Modern Politics. London: Europa Publications.

Sartori, G. 1984. Guidelines for Concept Analysis in G. Sartori, ed. Social Science Concepts: a Systematic Analysis. Beverley Hills: Sage: 15-44.

Tarrow, S. 1990. Maintaining Hegemony in Italy: 'The softer they rise the slower they fall!' In T. J. Pempel, ed. Uncommon Democracies. The One-Party Dominant Regimes. Ithaca: Cornell University Press: 306-32.

\section{Acknowledgements}

I thank two of the journal's anonymous referees for their suggestions and the Collegio Carlo Alberto, Turin, where a Research Fellowship in 2010 allowed the completion of the article.

\section{Notes}

${ }^{1}$ Indeed, it would be tempting to argue that Newell's 'man that never was' never had been for some of us. However, a trawl through my own work would reveal its inconsistencies on this front. My modest claim would be that I was an early skeptic (see Bull 1997, Bull 1998).

${ }^{2}$ Newell's argument, in fact, is made in the context of the 2008 elections, so it is not intended to be developed in a wider manner.

${ }^{3}$ There is now a vast literature on the political changes since the early 1990s. For a flavour, see Caciagli et al. (1994), Bull and Rhodes (1997), and Bull and Rhodes (2009).

${ }^{4}$ And comparative political scientists (i.e. non-Italian specialists) were relatively quiet in commenting on the Italian case.

5 'As is well known, though often neglected and underestimated in its concrete consequences, the Italian regime has been in transition since 1993.' (Pasquino 2007, 277). See also Grilli di Cortona 2007). The exact date, however, was always open to question (see Pasquino 1997, 34 and note 2, 51-2).

${ }^{6}$ Historians, of course, use 'transition' without concern for the time span, but the word has not been developed conceptually as it has in political science (see note 7 below).

${ }^{7}$ Symptomatic of the persistence of this debate was the inclusion of 'Second Republic' in the $3^{\text {rd }}$ edition of David Robertson's Dictionary of Modern Politics, where he notes that 'the phrase ["Second Republic"] has entered the terminology of political science. The idea that Italy is now living under a second constitution arises from the sense that the changes were so extreme as to amount to a peaceful revolution...', even though 'Technically there is no Second Republic' (Robertson 2002, 254-5).

${ }^{8}$ Of course, by implication, this suggests that much of the literature was a lot more casual in its use of transition. Indeed, 'transition' was often used quite loosely by political scientists (besides its use in other disciplines such as history) and echoed a tradition dating back to the 1970s (e.g. Lange and Tarrow 1979). Evidently, however, this would be no defence for those political scientists who have used the words to advance an argument that Italy is undergoing a transition to, or arrival at, a Second or Third Republic, without exploring the meaning of concepts such as 'transition' and 'regime'.

${ }^{9}$ Although he was also at pains to point out the differences and difficulties, arguing that other countries such as Spain and Central East Europe should also be considered, and that 'the Italian transition deserves to be treated in a comparative perspective in a very flexible way' (Pasquino 1994: 2-5 \& 8; and Pasquino 2007).

${ }^{10}$ See also Allum and Newell $(2003,181)$, where the title of first section of their article is 'Italy's "uniqueness"; and Fabbrini's 'transition without transformation' (2000) appears to have been constructed to capture the Italian case. 
${ }^{11}$ Which is not to say that viewing the Italian case on its own terms is always necessarily wrong (see Newell 2004) or that the Italian case might be seen as still 'anomalous' in other (related) terms (see, for example, Bull and Newell 2009).

${ }^{12}$ On the difficulties arising from the profusion of concepts with qualifying adjectives see, for example, Armony and Schamis (2005) and Collier and Levitsky (1997).

${ }^{13}$ This is not to question the value of much of this detailed research, only its implicit or explicit framing by an overall transitional paradigm. For a discussion of the problem, and an attempt to overcome it in relation to writing about the political system as a whole, see Bull and Newell (2005, 1-3 and ch. 1).

${ }^{14}$ This is not to imply criticism of the way this sentence attempts to capture the Italian case (indeed, Newell and I used it in our book to help shape our approach - Bull and Newell 2005), nor even of the phrase 'of sorts', which quite neatly captures the essential dilemma confronting Italianists in this period (for analogous use see Bull and Newell 1997).

${ }^{15}$ This may explain why more recent attempts to capture the political change Italy has undergone since the early 1990s have focused as much on the 'point of arrival' as the 'point of departure' e.g. Morlino (2009) and Fabbrini (2009). On the one hand, these approaches give a clear sense of the type of 'regime' change to be expected; on the other hand, they run the risk of being (wittingly or unwittingly) associated with the logic of the 'transitional' approach i.e. by using an 'end-point' to evaluate the change that has thus far occurred, there is an implicit assumption that future developments are likely to be in the same direction until that end-point is reached. Fabbrini $(2009,44)$ is fairly clear on this expectation, Morlino $(2009,24)$ argues that it is, in fact, impossible.

${ }^{16}$ Some British specialists might even cite their own case based on the process underway following devolution.

${ }^{17}$ Space only permits the introduction of these issues, not their development, which is for future work.

${ }^{18}$ Pasquino's distinction between 'challenges to the regime' and 'challenges to the performance of a regime' and the outcomes they can produce (2001) provides a basis for exploring some of the issues outlined here.

${ }^{19}$ For attempts in this direction see, for example, Morlino (2009) and Fabbrini (2009), which are based on 'models of democracy' (à la Lijphart).

${ }^{20}$ For an excellent example which shows an awareness of the complexities at the sub-system level, see Bardi (2009).

${ }^{21}$ For example, Calise (2006, 3 \& 12), besides arguing for the existence of a Third Republic, notes, at the same time, that Italy remains in transition.

${ }^{22}$ The contrast with science is useful here to illuminate the argument. A biologist, for example, knows - from scientific analysis and repeated observation of the same process - that, once a chrysalis is formed, a butterfly will emerge. He or she also knows roughly how long this process will take and what are its chief characteristics. It is therefore entirely legitimate to describe a chrysalis as a 'transitional' state. Political scientists are not in a position to predict regime changes and outcomes with such certainty (I am grateful to one of the anonymous referees for drawing my attention to this comparison). ${ }^{23}$ Inevitably, what follows is only an outline of the argument.

${ }^{24}$ Moreover, while at one level all of this might appear to be a rather 'closed' and not very useful debate between Italianists about 'transition', it might also be suggested that this debate, in fact, exercised an influence on the high expectations generated about Italian politics in the 1990s, expectations which help explain the pessimism of the subsequent decade, when they were widely felt to have been dashed. 